\title{
New records of Convolvulaceae species for the Ceará state and its potential geographic distribution in Northeast Brazil
}

\author{
Diego Santosa, Ketley Gomes Camposa, Marlene Feliciano Figueiredob, Edson Gomes de Moura \\ Júniorc, Maria Teresa Burila* \\ a Programa de Pós-Graduação em Botânica, Universidade Federal Rural de Pernambuco, Recife, 52171-030, Pernambuco, Brazil. \\ *fdsantosbot@gmail.com \\ b Universidade Estadual Vale do Acaraú, Sobral, 62040-370, Ceará, Brazil. \\ c Universidade Federal do Vale do São Francisco, Petrolina, 56304-917, Pernambuco, Brazil.
}

Received: November 8, 2019 / Accepted: December 12, 2019 / Published online: January 20, 2020

\begin{abstract}
This study reports six new records of Convolvulaceae for Ceará state, notheastern Brazil: Ipomoea aristolochifolia G.Don, Ipomoea calyptrata Dammer, I. cynanchifolia Meisn, I. longibracteolata Sim.-Bianch. \& J. R. I. Wood,I. meyeri G. Don and Jacquemontia mucronifera (Choisy) Hallier f. Of these, I. longibracteolata and I. meyeri are new records for the Atlantic Forest and Caatinga, respectively. For each species registered are provided descriptions, taxonomic and ecological comments, illustrations or photos of diagnostic characters and an ecological niche modeling analysis in northeast Brazil.
\end{abstract}

Keywords: Atlantic forest, Caatinga, new occurrences, ecological niche modeling.

\section{Novos registros de Convolvulaceae para o estado do Ceará e sua distribuição potencial no Nordeste do Brasil}

\begin{abstract}
Resumo
Este estudo reporta seis novos registros de Convolvulaceae para o estado do Ceará, nordeste do Brasil: Ipomoea aristolochifolia G.Don, Ipomoea calyptrata Dammer, I. cynanchifolia Meisn, I. longibracteolata Sim.-Bianch. \& J. R. I. Wood, I. meyeri G. Don e Jacquemontia mucronifera (Choisy) Hallier f. Destas, I. longibracteolata e I. meyeri são novos registros para a Mata Atlântica e Caatinga, respectivamente. Para cada espécies registrada, apresentamos descrições, comentários taxonômicos e ecológicos, ilustrações e fotografias de caracteres diagnósticos, e uma análise de modelagem de nicho ecológico para a região Nordeste do Brasil.
\end{abstract}

Palavras-chave: Mata Atlântica, Caatinga, novas ocorrências, modelagem de nicho ecológico.

\section{Introduction}

Convolvulaceae comprises about 1,800 species distributed in 59 genera occurring mainly in the tropical region, with few representatives in temperate areas (WCSP, 2018). Brazil is considered a center of diversity and holds the largest number of endemic species of Convolvulaceae in the Americas (Austin $\&$ Cavalcante, 1982). About 416 species and 24 genera (BFG, 2018) are recorded, many of which are present in areas with open vegetation, such as Caatinga and Cerrado, and edges of forest formations (Bianchini, 1998).

The family is characterized as herbs, shrubs, rarely holoparasites (Cuscuta), trees (Humbertia) and, most frequently climbers; with alternate leaves, simple or compound; sepals free; corolla gamopetalous with mesopetal bands; ovary super, style usually terminal. It is monophyletic without morphological synapomorphies (Stefanovic, 2003) and is included in Solanales as sister group of Solanaceae (APG IV, 2016). Among Convolvulaceae genera present in 30
Brazil, Ipomoea L. stands out with higher species richness (149 spp.) followed by Jacquemontia Choisy (66 spp.) and Evolvulus L. (73 spp.). In the Northeast, these three genera together represent 79\% (154 spp.) of the family (BFG, 2015).

Although Ipomoea is morphologically variable, it is easily recognized by having globose stigmatic lobes, echinate pollen grains and 4-valvar capsules. While Jacquemontia is recognized for presenting stellate trichomes, ellipsoid stigma and 8-valvar capsules, and Evolvulus presents malpighiaceous trichomes, filiform stigmas and 4-valvar capsules (Austin \& Cavalcanti, 1982).

During the study of Convolvulaceae species richness in Ceará, carried out between 2015 and 2018, we found six species that had never been reported to the state: $I$. aristolochifolia G.Don, Ipomoea calyptrata Dammer, I. cynanchifolia Meisn, I. longibracteolata Sim.-Bianch. \& J. R. I. Wood, I. meyeri G. Don and Jacquemontia mucronifera (Choisy) Hallier f.. Besides that, I. longibracteolata and I. 
meyeri were recorded for the first time in the Atlantic Forest and Caatinga, respectively. Considering the importance of understanding species' distributions and their distribution patterns, morphological and ecological profile, in addition to providing data to assess their conservation status, we discuss these new records herein.

\section{Material and Methods}

Field collections were carried out in areas of Atlantic forest and Caatinga, in the municipalities of Meruoca, Alcântara and Graça (Ceará). Specimens were georeferenced and processed according to Peixoto et al. (2013) and deposited at HUVA with duplicates sent to EAC and PEUFR. Identifications were based on specific literature (Simão-Bianchini, 1998; Buril, 2013) and confirmed by the analysis of protologues and high resolution images of type material available online at Jstor (https://plants.jstor.org/). The following herbarium were analyzed: EAC, HCDAL, HUVA, HST, HVASF, IPA, MOSS, PEUFR, UFP, UFRN (acronyms follows Thiers, 2018). Morphological terminology follows Gonçalves and Lorenzi (2011).

The geographic distribution is in accordance with specialized literature (Austin \& Huámam, 1996) and online databases (http://floradobrasil.jbrj.gov.br/). Flowering and fruiting period were based on personal observations in the field. Diagnostic characters for each species were illustrated. Environmental Distance algorithm was used for Species Distribution Modeling (SDM). For each species, models using two metrics of Environmental Distance (Gower or Euclidian) were applied with 5000 interactions each (Carpenter et al., 1993). Nineteen layers of bioclimatic variables exported from WordClim (Hijmans et al., 2005) and CGIAR-CSI databases (Zomer et al., 2007, 2008) were chosen, with pixels of $10 \mathrm{~km}^{2}$ and Northeast Brazil as background.

Before the SDM, we applied Principal Component Analysis (PCA) to select some environmental variables (Moura-Júnior et al., 2016). Thus, the environmental variables data was used in the background pixels. The environmental variables selected were: Temperature Annual Range (Bio 7), Mean Temperature of Coldest Quarter (Bio 11), Precipitation of Wettest Quarter (Bio 16), Precipitation of Driest Quarter (Bio 17), and aridity index (Ia). For each species, we chose the best performance model. We used Area Under the Curve (AUC) of the Receiver Operating Characteristic (ROC) to evaluate the performance of the models (Phillips et al., 2006). We defined Threshold ("minimum threshold of presence" criterion) to distinguish similar or dissimilar environments to those with species records (Pearson et al., 2007). We used the Geographic Information System (GIS) of the ArcGis 10.2 software to elaborate the maps and the OpenModeller 1 software to compute the models (Munoz et al., 2011). Finally, we used the software $\mathrm{R}$ ( $\mathrm{R}$ CORE, 2018) vegan package to compute the PCA.

\section{Results and Discussion}

Here, we present morphological descriptions for each taxon, taxonomic and distribution notes, as well as information on their potential distribution in northeastern Brazil.

1. Ipomoea aristolochiifolia G. Don, Gen. Hist. of the
Dichlamydeous Plants 4: 277. 1838. (Figures 1A-C, 2A)

Type: Venezuela, entre Caracas e La Venta de la Cumbre, Bonpland 679 (P670751 [digital image!]).

Conservation status: not evaluated (NE)

Creeper; stem and branches glabrous to glabrescent, not latescent. Leaf blade 1.5-6 × 1-5 cm, cordiform, base cordate, apex acute, acuminate, margin entire, occasionally with small lobes, both faces glabrous, with delicate veins, concolor; petiole 0.3-6.0 cm long, canaliculate, glabrous. Inflorescence with few 1-3 flowers; peduncle 1-4 cm long, glabrous, passing between the basal lobes of the leaf blade; bracteoles ca. $1 \mathrm{~mm}$ long, ovals, base truncate, apex acute, glabrous; pedicel $0.7-1 \mathrm{~cm}$ long, glabrous. Sepals $0.4-0.5 \times$ $0.2 \mathrm{~cm}$, closely oval, flat, base obtuse to truncate, apex obtuse to acute, glabrous, with longitudinal riges in the median region. Corolla 1.6-2.5 × 2-2.5 cm, funnel-shape, sericeous mesoptala area, blue with target tube, without sharp appendages at the base of the filets. Fillets ca. $2.5 \mathrm{~cm}$ long, in the basal region; anthers ca. $3 \mathrm{~mm}$ compr., oblongs, white. Ovary ca. $4 \mathrm{~mm}$ long, globoid and glabrous; stylet ca. $2 \mathrm{~cm}$ long, glabrous; globular stigma. Capsule 7-8 $\times 7 \mathrm{~mm}$, ovoid to conic, glabrous, apiculate. Seeds not seen.

Distribution notes: This species is widely distributed in the Americas (Austin and Huamam 1996). In Brazil, it is distributed in all regions and was initially only known to the Amazonia, Cerrado and Atlantic Forest domains (BFG 2015). A small population of this species was found in areas under the influence of animal grazing, Meruoca massif, in Caatinga vegetation, in Ceará state. Currently this massif is being targeted by real estate construction, making the species vulnerable to local extinction. Species Distribution Modeling (SDM) analysis shows the Environmental Protection Conservation Unit of the Araripe Plateau as a potential distribution area of I. aristolochifolia (Figure 3A), demonstrating the importance of this area for maintaining this species in nature.

Taxonomic notes: This species is identified by the combination of its voluble habit, presence of peduncle passing between the foliar base lobes and longitudinal crests in the median region of the external sepals, funnel-shape and blue with target tube corolla.

Examined material. BRAZIL. Ceará: Sobral, Sítio Santa Cruz, Trilha do Delta, 22 Jul 2015, fl. fr., E.B. Souza 3665 (HUVA).

2. Ipomoea calyptrata Dammer, Botanische Jahrbücher für Systematik 23(5): 40. 1897. (Figures 1D-F, 2B)

Type: Brazil, Minas Gerais, Araçuai, Glaziou 15265, 06.III.1883 (F0BN013798 [digital image!], K612835 [digital image!], P03878984 [digital image!], R12316 [digital image!]).

Conservation status: data deficient (DD)

Liana, stem and branches pubescent, latescent. Leaf blade $2.0-17 \times 3.0-16 \mathrm{~cm}$, cordiform, ovate, base cordate, apex obtuse to acute, margin entire, pubescent abaxial face, sparsely pubescent to glabrescent adaxial face, densaly pubescent abaxial face, robust veins, discolor; petiole 2.5-15 cm long, canaliculate, pubescent. Inflorescence 3-12 
flowers; peduncle $1.0-8.5 \mathrm{~cm}$ long, pubescent, not passing between the basal lobes of the leaf blade; bracteoles 1.5-2.0 $\times$ $0.7-1.0 \mathrm{~cm}$, cimbiform to obovates, base obtuse, cuneate, apex obtuse, rounded, pubescent; pedicel $0.3-1.0 \mathrm{~cm}$ long, pubescent. Sepals 1.0-1.6 × 0.7-1.0 cm, elliptical, ovate, flat, base obtuse, apex obtuse, tomentose, smooth. Corolla 6.0-8.0 $\times 7.0-8.0 \mathrm{~cm}$, funnel-shape, glabrous mesopetal area, pink. Absent appendages at the base of fillets. Fillets ca. $3 \mathrm{~cm}$ long, pilose in region basal; anthers ca. $5 \mathrm{~mm}$ long, oblongs, white. Ovary ca. $4 \mathrm{~mm}$ long, globoid, glabrous; stylet ca. $3.5 \mathrm{~cm}$ long, glabrous. Capsule 1.3-1.5 $\times 1.1-1.2 \mathrm{~cm}$, globular, glabrous, not apiculated. Seeds $0.9-1.0 \times 0.6-0.7 \mathrm{~cm}$, velutins.

Distribution notes: This species is endemic to Brazil, occurring in areas of Caatinga and Cerrado (BFG 2015). It was initially known in states of Bahia (Northeast region) and Minas Gerais (Southeast region), with its distribution extended to Ceará state herein. In North Ceará, the species was collected in rocky outcrops associated with the Sub-Perennifolia Pluvial-Nebular Rainforest in sandy soils. The Species Distribution Modeling (SDM) analysis shows that the crystalline massifs and the Environmental Protection Conservation Units of the Araripe and Ibiapaba Plateau present areas that favor the occurrence of this species (Figure 3B).

Taxonomic notes: We found specimens of $I$. calyptrata erroneously identified as $I$. subincana in local herbarium collections (EAC, HUVA). According to analysis of protologues and images of the type collection, both species share leaves with tomentose sepals, which probably caused this taxonomic confusion. However, they differ by the morphology of bracteoles (cimbiform bracteoles in I. calyptrata vs lanceolate in I. subincana). Ipomoea calyptrata can also be confused with I. brasiliana, differing from it by the indumenta of the sepals (tomentose in I. calyptrata vs. glabrous in $I$. brasiliana).

Examined material: Meruoca, Sítio Santo Inácio, 05 Mai 2014, fl., fr., F.D.S. Santos 57 (HUVA); idem, 13 Nov 2014, fl., fr., F.D.S. Santos 192 (HUVA); Idem, Sítio Santo Antônio, $25 \mathrm{Fev}$ 1981, fl., A. Fernandes s.n (EAC 9707). Itapipoca, Maciço de Uruburetama, Pico de Itacoatiara, 05 Mai 2014, fl., fr., F.D.S. Santos 57 (HUVA); Idem, Maciço de Uruburetama, Pico de Itacoatiara, 13 Nov 2014, fl., fr., F.D.S. Santos 192 (HUVA).

3. Ipomoea cynanchiifolia Meisn, Flora Brasiliensis 7: 274. 1869. (Figures 1G-I, 2C)

Type: Brazil, Minas Gerais, Lagoa Santa, Warming s.n. (Lectotype BR697291 [digital image!], designed by O'Donell (1952); isolectotype P03548478 [digital image!].

\section{Conservation status: data deficient (DD)}

Creepers, stem and branches hirsute, not latescent. Leaf blade $2-7.5 \times 1.5-5 \mathrm{~cm}$, cordiform, base cordata, apex acuminate, margin entire, both velutins faces, delicate veins, slightly discolor; petiole 1-7.5 cm long, canaliculated, hirsute. Inflorescence 3-8 flowers; peduncle $1.3-5.5 \mathrm{~cm}$ long, hirsute, not passing between the basal lobes of the leaf blade; bracteoles ca. $1 \mathrm{~mm}$ long, lanceolate, base truncate, apex acute, glabrous; pedicel $3-7 \mathrm{~mm}$, glabrous. Sepals $4 \times 2-3.5 \mathrm{~mm}$, obovates, flat, base truncate, apex rounded to obtuse, occasionally apiculate, glabrous. Corolla 1.6-2.5 × 2-2.7 cm, funnel-shape, glabrous mesopetal area, pink, with internally dark, absent appendages at base of fillets. Fillets ca. $2.5 \mathrm{~cm}$ long, glabrous; anthers ca $3.5 \mathrm{~mm}$ long, oblogs, white; Ovary ca $2.5 \mathrm{~mm}$ long, ovoid, glabrous; stylets ca. $3 \mathrm{~cm}$ long, glabrous. Capsule 5-6 mm long, ovoid to ellipsoids, glabrous, apiculated. Seeds not seen.

Distribution notes: Ipomoea cynanchiifolia occurs in Bolívia, Brasil and the Guianas (Austin and Huamam 1996). In Brazil, it is widely distributed in all regions, except the South, in the Amazon, Caatinga, Cerrado and Atlantic Forest (BFG 2015). In the Northeast region, the species was initially known in the states of Bahia and Maranhão. Herein we extended its distribution to the state of Ceará, where a small population was found on the roadside, in sandy-loamy soils. Species Distribution Modeling (SDM) analysis shows that the Environmental Protection Conservation Units of the Araripe and Ibiapaba Plateau present areas that favor the occurrence of I. cynanchiifolia (Figure 3C).

Taxonomic notes: This species can be identified by presenting cordiform, velutins leaves; discolor, leaf margin; sepals up to $4 \mathrm{~mm}$ long, glabrous, and pink corolla with internally dark tube.

Examined material: Meruoca, estrada para o Sítio Santo Inácio (-03.54167, -040.45500), 11.V.2015, fl., fr., F.D.S. Santos 322 (HUVA, PEUFR).

4. Ipomoea longibracteolata Sim.-Bianch. \& J. R. I. Wood, Kew Bulletin 72(1): 8-15. 2017. (Figures 1J-L, 2E)

Type: Brazil, Bahia, Mun. Caetité, Faz. Baixa Grande, 1404'03"S 42³8'12"W, 820 m, 9 Feb. 1997, M. L. Guedes, B. Stannard, E. Saar \& L. Passos 5276 (holotype HUEFS28895!; isotypes ALCB!, CEPEC, HRB, K, SPF).

Conservation status: data deficient (DD)

Creepers, stem and branches hirsute, latescent. Leaf blade 8.0-20 × 9.5-16 cm, cordiform, ovate, base cordata, apex acuminate, margin entire, both hirsute faces, robust veins, concolor; petiole 5.5-20 long, canaliculate, hirsute. Inflorescence with 1-3 flowers; peduncle $8.5-13 \mathrm{~cm}$ long, hirsute, not passing between the basal lobes of the leaf blade; bracteoles 1.6-4.0 × 1.1-2.4 cm, cimbiform, obovate, ellíptical, base cuneate, apex rounded, retuse, hirsute; pedicel $0.6-1.0 \mathrm{~cm}$ long, hirsute. Sepals unequal, 2 externas ellíptical $2.4-2.7 \times 1.7-1.8 \mathrm{~cm}$, base truncate, obtuse, apex rounded, margin entire, sparselly hirsute, smooth; inner 2.1-2.4 × 1,3$1.5 \mathrm{~cm}$, oblong, base truncate, apex obtuse to rounded, margin entire, glabrescent, smooth. Corolla ca. $7.5 \mathrm{~cm}$ long, campanulate, glabrescent mesopetal area, margenta fauce with white lacinia,absent appendages at base of fillets. Fillets ca. $1.5 \mathrm{~cm}$ long and with pilose base; anthers ca. $9 \mathrm{~mm}$ long, sagitates, white; Ovary 2-3 mm long, conic, glabrous; styles ca. $3.7 \mathrm{~cm}$ long, glabrous, globular stigma. Capsule not seen.

Distribution notes: Ipomoea longibracteolata was described for the states of Bahia, Goiás and Piauí, in the Cerrado and Caatinga domains (Wood, 2017). We expanded the distribution of this species to Ceará state, where it was collected in remnants of Atlantic Forest domain, in the Ubajara National Park and in the Meruoca massif, being its first record for the domain. 


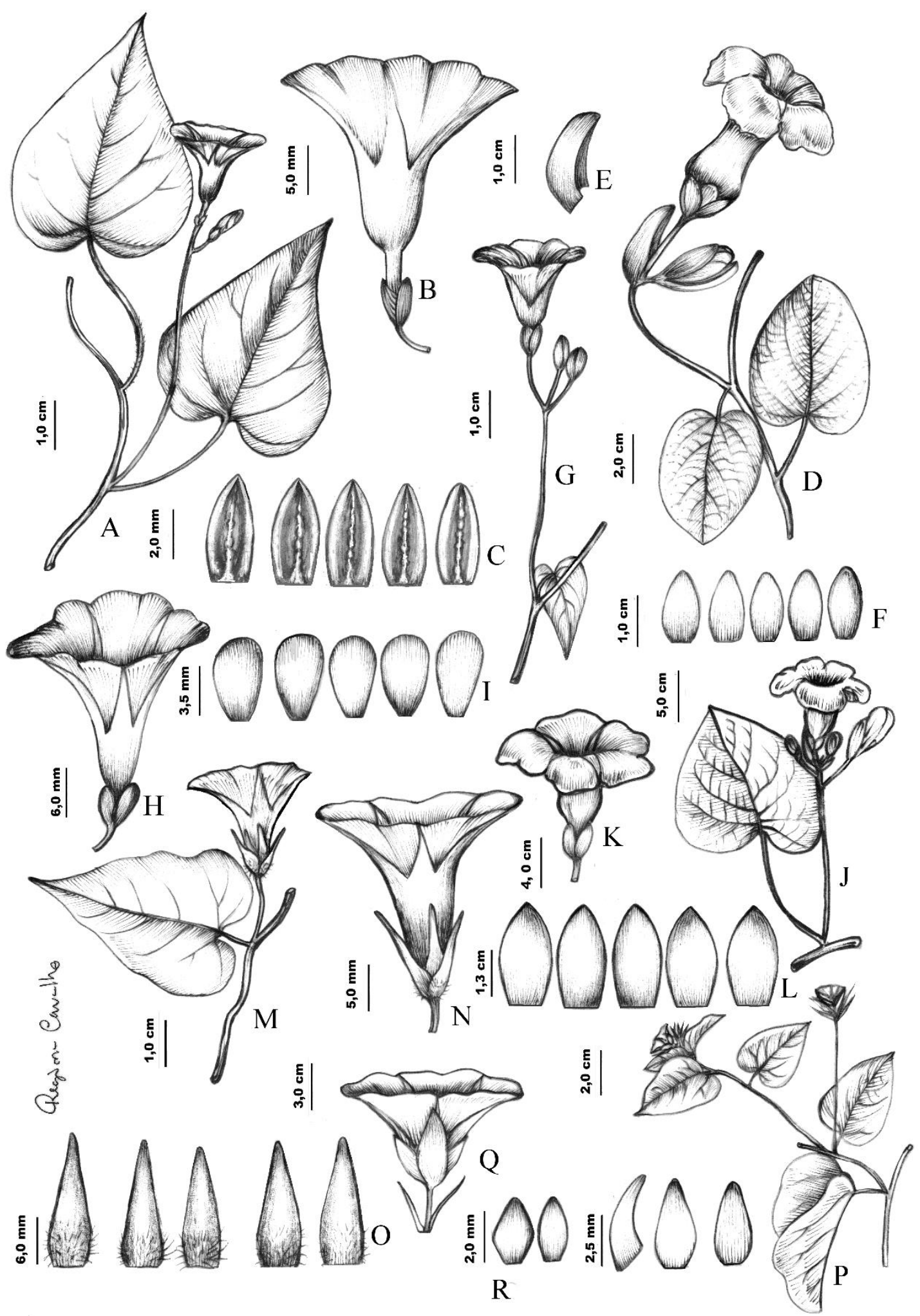

Figure 1. Diagnostic characters of the new records in Convolvulaceae. A-C. Ipomoea aristolochiifolia: A. branch with inflorescence; B. flower; C. sepals with longitudinal riges in the median region; from E.B. Souza 3665 (HUVA). D-F. Ipomoea calyptrata: D. branch with flower; E. bracteole; F. sepals; from F.D. Santos 192 (HUVA). G-I. Ipomoea cynanchiifolia: G. branch with inflorescence; H. flower; I. sepals; from F.D. Santos 322 (HUVA). J-L. Ipomoea longibracteolata: J. branch with inflorescence; K. flower; L. sepals; from F.D. Santos 301 (HUVA). M-O. Ipomoea meyeri: M. branch with inflorescence; N. flower; O. sepals; from A.F.B. Silva 07 (HUVA). P-R. Jacquemontia mucronifera: P. branch with inflorescence; Q. flower; R. detail of sepals; from A.C. Alcântara 38 (HUVA). 

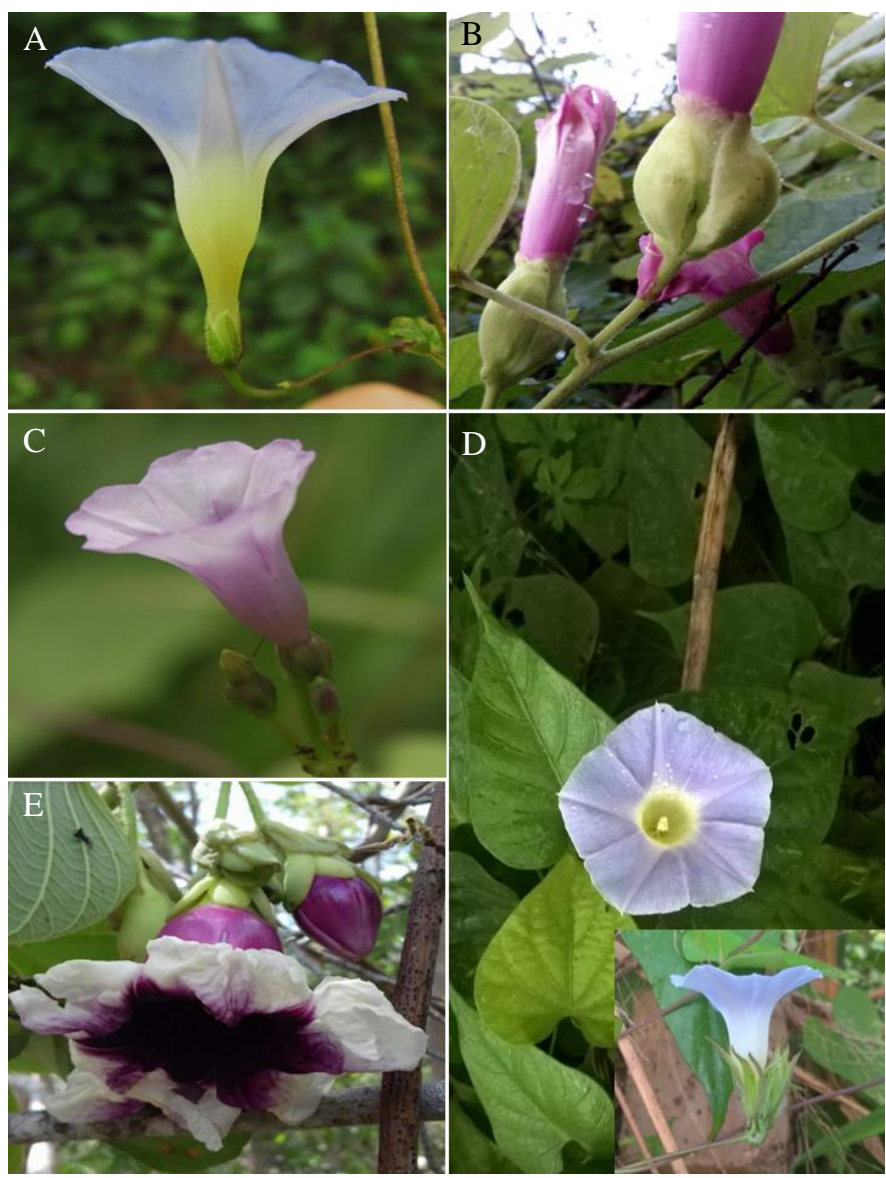

Figure 2. New records of Convolvulaceae. A. flower of the $I$. aristolochiifolia. B. detail of the bracteole of I. calyptrata. C. flower of I. cynanchiifolia. D. detail of flower of I. meyeri. E. Ipomoea longibracteolata. Photos by: F.D. Santos.

The Species Distribution Modeling (SDM) analysis shows that Conservation Units in the Ibiapaba and Araripe Plateau present areas that favor the occurrence of I. longibracteolata (Figure 3D).

Taxonomic notes: This species can be identified by its stems with rigid trichomes, bracteoles $2-3 \times 0.6-1.3 \mathrm{~cm}$, naviculares, oblong, elliptical, persistent and by compact inflorescences (Wood, 2017).

Examined material: Meruoca, Sítio Santa Maria, 730 m alt, 11 Abr 2017, fl., F.D.S. Santos 301 (HUVA).

5. Ipomoea meyeri (Spreng.) G. Don, General History of the Dichlamydeous 4: 275. 1837. (Figures 1M-O, 2D)

Type: s.1. Meyer s.n (B, W [digital image!]).

Conservation status: not evaluated (NE)

Creepers, stem and branches hirsute, latescent. Leaf blade 2-7 $\times 1.7-5 \mathrm{~cm}$, cordiform to trilobada, base cordata, apex acute to acuminate, whole or lobet margin, pilose, delicate veins, slightly discolor; petiole $1.0-8.0 \mathrm{~cm}$ long, canaliculate, hirsute. Inflorescence 3-8 flowers; peduncle 2-12 cm long, pilose; bracteoles 1.5-4, lanceolate, base truncate, apex acute to acuminate, glabrous, foliaceus; pedicel $0.5-1.0 \mathrm{~cm}$ compr., glabrous. Sepals $1.7-1.8 \times 0.3-0.4 \mathrm{~cm}$, lanceolate, flat, base obtuse, apex acute, hirsute on base. Corolla $2.5-3 \times 2-2.2 \mathrm{~cm}$, funnel shape, glabrous mesopetal, pink, absent appendages at base of fillets. Fillets ca. $2 \mathrm{~cm}$ long, glabrous; anthers ca. $5 \mathrm{~mm}$ long, oblong, white; Ovary ca. $2 \mathrm{~mm}$ lonh, ovoid, glabrous; stylets ca. $2.5 \mathrm{~cm}$ long, glabrous. Capsule 5-7 mm long, globular, glabrous, apiculate. Seeds $3.5-4 \times 2.5-3 \mathrm{~mm}$, glabrous.

Distribution notes: Ipomoea meyeri occurs throughout Central and South America (Austin and Huamam 1996). In Brazil, the species is naturalized, and it was first known in Maranhão state, in the Amazon domain (BFG 2015). Here, we expanded its distribution to Ceará state, where a small population was found in an anthropic area in the Caatinga domain, in sandy-clay soils (Figure 3E), representing the second record for Brazil and the first for the Caatinga domain. The Species Distribution Modeling (SDM) analysis shows that the Conservation Unit in the Araripe Plateau presents areas that favor the occurrence of I. meyeri (Figure 3E).

Taxonomic notes: The species can be confused with I. nil for sharing stem and leaf hirsute and sepals with base hirsute, differing from this by presenting elliptic bracteoles ( $v s$ linear), ovate to elliptic sepals with long-acuminate apex (vs lanceolate, apex acute).

Examined material: Graça, estrada para o Sítio Santo Inácio, 11 Mai 2015, fl. fr., A.F.B. Silva 07 (HUVA).

6. Jacquemontia mucronifera (Choisy) Hallier f., Botanische Jahrbücher für Systematik 16: 543. 1893. (Figures 1P-R)

Type: Brazil, Minas Gerais, Martius s.n (M0184723 [digital image!]).

Conservation status: not evaluated (NE)

Creepers, stem and braches with starry trichomes. Leaf blade $2-8 \times 1.5-7 \mathrm{~cm}$, cordiform to oval, base cordate, apex acuminate, margin entire, velutine, slightly discolor; petiole 0.5-4.0 cm long, not canaliculate starry trichomes. Inflorescencia 3-18 flowers; peduncle 0.5-10.5 cm long, with starry trichomes; bracteoles $0.3-1.0 \mathrm{~cm}$ long, linears, starry indument; pedicel 1-3 $\mathrm{mm}$ long. Sepals unequal, externas 5-7 × 2-3 mm long, rhomboids to lanceolate, flat, base cuneate, apex acute, margin entire, escarious; intermediary 4-6 $61.5 \mathrm{~mm}$, falcate, asymmetric, base cuneate, apex acuminate, starry indument restricted to a margin; inner 2.5-4 × 1-2 mm, ovates, flat, base obtuse, apex acuminate, starry indumenta restricted to the median region. Corolla $0.7-0.9 \times 1.2-1.5 \mathrm{~cm}$, funnel shape, mesopetal área, glabrous, blue. Fillets ca. $4 \mathrm{~mm}$ long, glabrous; anthers ca. 2 $\mathrm{mm}$ long, oblong, white; Ovary ca. $1.5 \mathrm{~mm}$ long, ovoid, glabrous; stylete ca. $5 \mathrm{~mm}$ long, glabrous, ellipsoid stigma. Capsule not seen.

Distribution notes: This species is endemic to Brazil, occurring in the Northeast, Southeast and South region, in the Cerrado and Atlantic Forest (BFG 2015). In the Northeast, Jacquemontia mucronifera was initially known in the states of Alagoas, Bahia, Pernambuco, Paraiba, Rio Grande do Norte and Sergipe. Here, we expanded its distribution to Ceara state, where it was registered on the roadside in sandy soils (Figure 3F). The Species Distribution Modeling (SDM) analysis shows that the Conservation Unit in the Araripe and Ibiapaba Plateau present areas that favor 
the occurrence of $J$. mucronifera (Figure 3F). Taxonomic notes: The species is recognized for having unequal sepals, external ones larger than internal ones and linear bracteoles.
Examined material: Alcântara, Sítio Maracujá, Maciço da Meruoca, 29 Abr. 2016, fl., A.C. Alcântara 38 (HUVA); Meruoca, Sítio Maracujá, Maciço da Meruoca, 20 Mai 2018, fl., A.C. Alcântara 38 (HUVA).
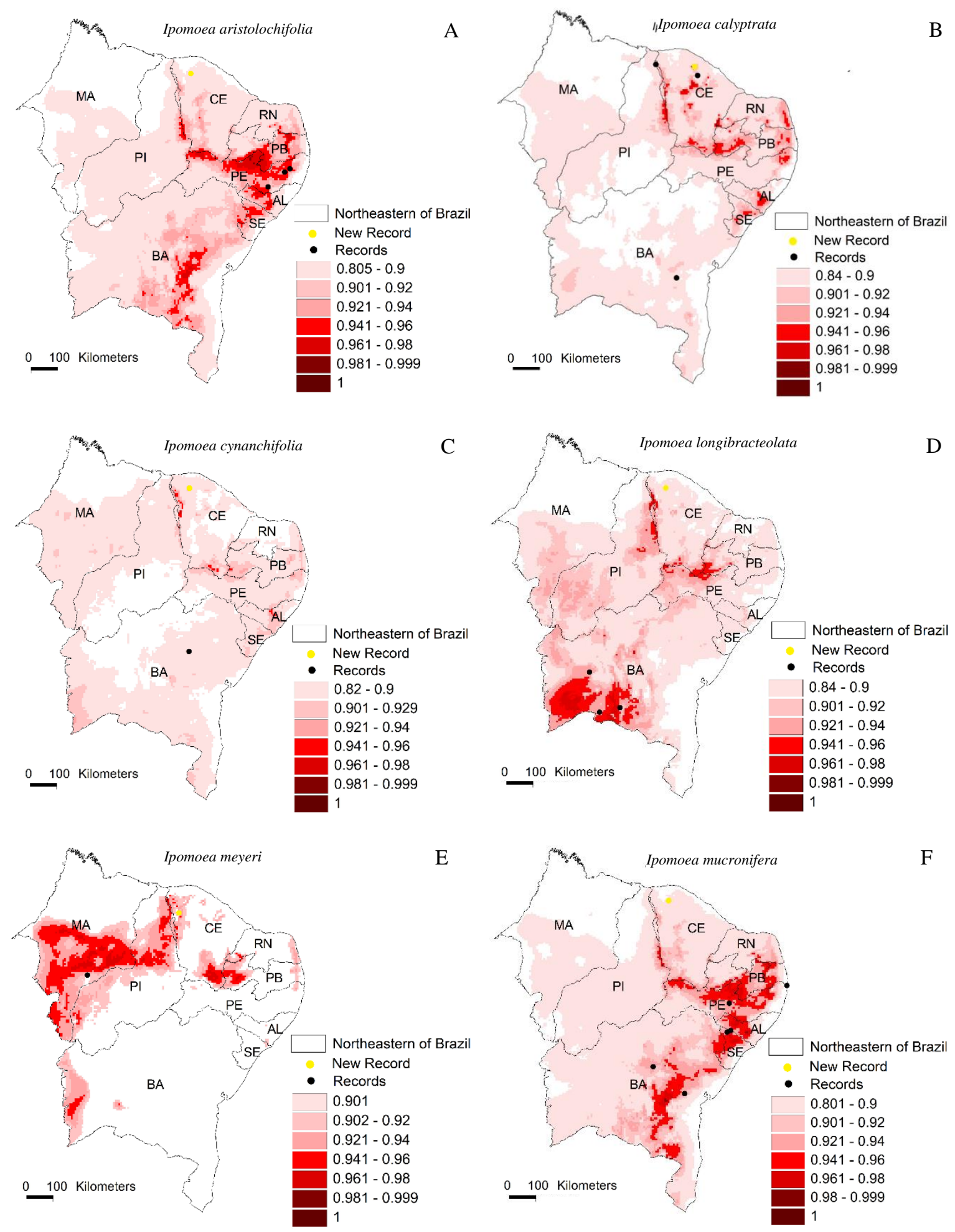

Figure 3. Map showing the location of new records for the Ceará state, and its potential distribution in the northeastern Brazil.

The knowledge of species geographic distribution is important for understanding of species distribution patterns, the biogeographical history of taxa, and patterns of endemism (Sylvestre, 2002). According to the flora website of Brazil, 96 species of Convolvulaceae were recorded for Ceará (Flora do Brasil 2020, under construction). Among these, 40 and 19 are represented by the genera Ipomoea and Jacquemontia, respectively. According to these results, we expanded the 
diversity of species this family for the state, which now presents 99 species (44 species of Ipomoea / 20 species of Jacquemontia), besides incrementing the diversity of Ipomoea species for the Caatinga and Atlantic Forest, with 51 and 61 species recorded, respectively. Although these domains present rich biodiversity (Milaré, 2011; Leal et al., 2005), they also present a high number of endangered species due to the high degrees of endemism, devastation and fragmentation (Ministério do Meio Ambiente, 2010), emphasizing the importance of additional studies in the cerrado and Atlantic Forest from Ceará for understanding of plant distribution patterns in northeastern Brazil.

Analysis of Species Distribution Modeling (SDM) shows that Conservation Units in the Araripe and Ibiapaba Plateau have adequate environmental conditions for most of these species, showing the importance of these units for preserving these taxa. Thus, the present work highlights the importance of greater collection efforts in the Ceará territory to investigate these new records in such Conservation Units. The modeling analysis also confirmed that the species recorded here may occur in other states in the Northeast region, as they present potential occurrence areas, reinforcing the importance of expanding collections in these states (Figure 3). Among the species registered, I. aristolochifolia and I. cynanchifolia are subject to local extinction, since they occur in areas that are currently occupied by real estate construction. Therefore, environmental managers of Ceará state should consider such factors when making decisions in selecting priority areas for their conservation. Such data will assist in assessing the conservation status of these species, since all the species recorded here are categorized as not evaluated (NE) or insufficient data (DD).

\section{Acknowledgements}

We thank the Coordenação de Aperfeiçoamento de Pessoal de Nivel Superior (CAPES) for the scholarship granted to the first and second authors, the Conselho Nacional de Desenvolvimento Científico and Tecnológico (CNPq/PVE 314725/2014-8) for funding the project "Convolvuláceas da América do Sul", the curators of the herbaria visited, Regina Carvalho for the illustrations and Hannah Doerrier for English review.

\section{References}

APG IV. (2016) An update of the Angiosperm Phylogeny Group classification for the orders and families of flowering plants: APG IV. Botanical Journal of the Linnean Society, 181(1): 1-20. doi:10.1111/boj.12385

Austin, D. F., \& Huáman, Z. (1996) A synopsis of Ipomoea L. (Convolvulaceae) in the Americas. Taxon, 45(2), 3-38.

Austin, D. F., \& Cavalcanti, P. B. (1982). Convolvulaceae da Amazônia. Publicações avulsas do Museu paraense Emilio Goeldi, 36: 1-132.

BFG. (2015). Growing knowledge: an overview of seed plant diversity in Brazil. Rodriguésia, 66(4), 1085-1113. doi:10.1590/21757860201566411

Ministério do Meio Ambiente. Secretaria de Biodiversidade e Florestas. Núcleo Mata Atlântica e Pampa. (2010). Mata Atlântica: Patrimônio Nacional dos Brasileiros. Brasília: Ministério do Meio Ambiente. Secretaria de Biodiversidade e Florestas. Núcleo Mata Atlântica e Pampa.

Buril, M. T. (2013) Sistemática e filogenia de Jacquemontia Choisy (Convolvulaceae). Tese de Doutorado, Universidade Federal de Pernambuco, Recife, PE.
Carpenter, G., Gillison, A. N., \& Winter, J. (1993) DOMAIN: A flexible modeling procedure for mapping potential distributions of animals and plants. Biodiversity and Conservation, 2(6), 667-680.

Gonçalves, E. G., \& Lorenzi, H. (2011) Morfologia vegetal: organografia e dicionário ilustrado de morfologia das plantas vasculares (2a ed.). São Paulo: Instituto Plantarum de Estudos da Flora.

Hijmans, R. J., Cameron, S. E., Parra, J. L., Jones, P. G., \& Jarvis, A. (2005). Very high resolution interpolated climate surfaces for global land areas. International journal of climatology, 25(15), 1965-78.

Milaré, E. (2011). Direito do Ambiente: a gestão ambiental em foco: doutrina, jurisprudência, glossário (7a ed.). São Paulo: Editora Revista dos Tribunais.

Moura-Júnior, E. G., Rodrigo, V. S., \& Milhomens, L. B. S. (2016). New record of Pithophora roettleri (Roth) Wittrock, 1877 (Chlorophyta: Pithophoraceae) for the São Francisco River basin and its potential geographic distribution in Brazil. Check List, 12(3), 1899.

Muñoz, M. E. S., Giovane, R., Siqueira, M. F., Sutton, T., Brewer, P., Pereira, R. S., Canhos, D., \& Canhos, V. P. (2011). "openModeller: a generic approach to species' potential distribution modelling". GeoInformatica, 15(1), 111-135.

Leal, I. R., Silva, J. M. C., Tabarelli, M., \& Lacher, T. (2005). Mudando o curso da conservação da biodiversidade na Caatinga do Nordeste do Brasil. Megadiversidade, 1(1), 139-146.

Ooststroom, S. J. V. (1934). A monograph of the genus Evolvulus. Mededeelingen van het botanisch museum en herbarium van de rijks universiteit te Utrecht, 14: 1-267.

O’Donell, C. A. (1952). Convolvulaceae Americanas Nuevas o Criticas 3. Arquivos do. Museu Paranaense Curitiba, 9(11), 207-244.

Pearson, R. G., Pearson, R. G., Raxworthy, C. J., Nakamura, M., \& Peterson, A. T. (2007). Predicting species' distributions from small numbers of occurrence records: a test case using cryptic geckos in Madagascar. Journal of biogeography, 34(8), 102-117.

Peixoto, A. L., \& Maia, L. C. (2013). Manual de Procedimentos para Herbários. INCT-Herbário Virtual para a Flora e os Fungos. Recife: Editora Universitária UFPE.

Phillips, S. J., Anderson, R. P., \& Schapired, R. E. (2006). Maximum entropy modeling of species geographic distributions. Ecological Modelling, 190(2006), 231-259.

R DEVELOPMENT CORE TEAM - R CORE. (2018). R: a language and environment for statistical computing. Vienna: R Foundation for Statistical Computing.

Simão-Bianchini, R. (1998). Ipomoea L. (Convolvulaceae) no Sudeste do Brasil. Tese de doutorado. Universidade de São Paulo, São Paulo, SP.

Staples, G. W. (2018). World Checklist of Convolvulaceae. Facilitated by the Royal Botanic Gardens, Kew. Published on the Internet.

Stefanovic, S., Austin, D. F., \& Olmstead, R. G. (2003). Classification of Convolvulaceae: A phylogenetic approach. Systematic Botany, 28(4) 797-806.

Thiers, B. (2018) [continuously updated]. Index Herbariorum: a global directory of public herbaria ans associated staff. New York Botanical Garden's Virtual Herbarium.

Wood, J. R. I., Carine, M. A., Harris, D., Wilkin, P., Williams, B., \& Scotland, Q. W. (2015). Ipomoea (Convolvulaceae) in Bolivia. Kew Bulletin, 70:(83) 31-155. doi: 10.1007/512225-015-9592-7

Wood, J. R. I., Vasconcelos, L. V., Simão-Binchini, R., \& Scotland, R. W. (2017). New species of Ipomoea (Convolvulaceae) from Bahia. Kew Bulletin, 72(76), 8. doi:10.1007/s12225-017-9678-5

Zomer, R. J., Bossio, D. A., Trabucco, A., Yuanjie, L., Gupta, D. C., \& Singh, V. P. (2007). Trees and Water: Smallholder Agroforestry on Irrigated Lands in Northern India. Colombo: International Water Management Institute.

Zomer, R. J., Trabucco, A., Bossio, D. A., Van Straaten, O., \& Verchot, L. V. (2008). Climate Change Mitigation: A Spatial Analysis of Global Land Suitability for Clean Development Mechanism Afforestation and Reforestation. Agriculture, ecosystems \& environment, 126(232), 6780 . 
License: Creative Commons CC BY 4.0

This article was published with open access for distribution under the terms of the Creative Commons Attribution License, which allows unrestricted use, distribution, and reproduction in any medium, provided the original work is properly cited. 